$4 \quad$ Indranil Mukherjee ${ }^{1 \#}$, Michaela M Salcher ${ }^{1}$, Adrian-Ștefan Andrei ${ }^{1^{*}}$, Vinicius

5 Silva Kavagutti ${ }^{1,2}$, Tanja Shabarova ${ }^{1}$, Vesna Grujčić ${ }^{3}$, Markus Haber ${ }^{1}$, Paul

6 Layoun $^{1,2}$, Yoshikuni Hodoki ${ }^{4}$, Shin-ichi Nakano ${ }^{4}$, Karel Šimek ${ }^{1,2}$, Rohit

7 Ghai ${ }^{1 \#}$

8

\section{A freshwater radiation of diplonemids}

\author{
${ }^{1}$ Department of Aquatic Microbial Ecology, Institute of Hydrobiology,Biology Centre of \\ the Czech Academy of Sciences, , Na Sadkach 7, 37005, České Budějovice, Czech \\ Republic
}

${ }^{2}$ Department of Ecosystem Biology, Faculty of Science, University of South Bohemia, Branišovská 1760, 37005, České Budějovice, Czech Republic

${ }^{3}$ KTH Royal Institute of Technology, Science for Life Laboratory, Department of Gene Technology, School of Engineering Sciences in Chemistry, Biotechnology and Health, Stockholm, Sweden

${ }^{4}$ Center for Ecological Research, Kyoto University, Otsu, Shiga, Japan

* Current address: Limnological Station, Institute of Plant and Microbial Biology, University of Zurich, Seestrasse 187, 8802, Kilchberg, Switzerland

Keywords: 18S amplicon sequencing/ CARD-FISH/ diplonemids/ freshwater lakes/ protists/ metagenomic $18 \mathrm{~S}$ rRNA assembly

Running Title: Diplonemids in freshwater lakes

${ }^{\#}$ Authors to whom correspondence should be addressed

Indranil Mukherjee (indranilmukherjee04@yahoo.com)

Rohit Ghai (ghai.rohit@gmail.com) 
39 Abstract

40 Diplonemids are considered marine protists and have been reported among the most

41 abundant and diverse eukaryotes in the world oceans. Recently we detected the presence

42 of freshwater diplonemids in Lake Biwa, Japan. However, their distribution and

43 abundances in freshwater ecosystems remain unknown. We assessed abundance and

44 diversity of diplonemids from several geographically distant deep freshwater lakes of the

45 world by amplicon-sequencing, shotgun metagenomics and CARD-FISH. We found

46 diplonemids in all the studied lakes, albeit with low abundances and diversity. We

47 assembled long $18 \mathrm{~S}$ rRNA sequences from freshwater diplonemids and showed that they

48 form a new lineage distinct from the diverse marine clades. Freshwater diplonemids are a

49 sister-group to marine isolates from coastal and bay areas, suggesting a recent habitat

50 transition from marine to freshwater habitats. Images of CARD-FISH targeted freshwater

51 diplonemids suggest they feed on bacteria. Our analyses of 18S rRNA sequences retrieved

52 from single cell genomes of marine diplonemids shows they encode multiple rRNA copies

53 that may be very divergent from each other, suggesting that marine diplonemid abundance

54 and diversity both have been overestimated. These results have wider implications on

55 assessing eukaryotic abundances in natural habitats by using amplicon-sequencing alone.

\section{Introduction}

58 Diplonemids appear as one of the more intriguing findings in amplicon-sequencing

59 surveys of the global oceans microbiota [1]. While the abundance and distribution of these

60 protists were nearly unknown till the last decade, they are now considered (based mainly

61 on metabarcoding approaches) as one of the most abundant and diverse microbial

62 eukaryotic group in the world oceans [2,3]. Marine diplonemid 18S rRNA sequences

63 exhibit high diversity and are the sixth most frequently recovered eukaryotic signatures in 
the world's oceans in amplicon-based surveys [3]. They appear to be more abundant in the mesopelagic zone of the oceans $[1,4]$. These discoveries have ignited interest in understanding the importance and distribution of these protists in other aquatic nonmarine ecosystems. Diplonemids are considered marine protists [5] and were till recently never reported from freshwater ecosystems. Our interest in studying the distribution of free-living kinetoplastids (a sister group of diplonemids) from freshwater lakes using kinetoplastid-specific primers accidentally led us to the discovery of freshwater diplonemids in deep freshwater lakes of Japan [6]. Similar to kinetoplastids, diplonemids are generally not targeted by commonly used eukaryotic V4 primers due to their divergent 18S rRNA genes $[7,8]$ and this explains their exclusion from most diversity studies in freshwater environments. This finding suggested that diplonemids are not limited to marine ecosystems and are likely present in other freshwater lakes of the world. To examine the distribution of diplonemids in freshwater habitats, we sampled seven deep freshwater lakes (different depths, both monthly time series and isolated samples) of various trophic statuses from Japan, Czech Republic, and Switzerland. The diversity and abundance of diplonemids were analyzed using PCR based amplicon sequencing, shotgun metagenomic sequencing and CARD-FISH analyses. Our results suggest a broad distribution (albeit with low abundance) of diplonemids in freshwater ecosystems, and the presence of one widespread freshwater clade that appears to be a radiation of known marine isolates.

\section{Results and Discussions}

6 Freshwater diplonemid $18 S$ rRNA gene sequences

A single diplonemid sequence (OTU_4) was described recently from the lakes Biwa and Ikeda using $18 \mathrm{~S}$ rRNA amplicon sequencing [6]. This sequence provided the first 
intriguing evidence for the existence of freshwater diplonemids, which have been until now considered as marine eukaryotes [5]. However, more conclusive evidence for the presence of these eukaryotes and their distribution in other freshwater habitats is lacking. As the first diplonemid sequence was described from Lake Biwa, in an effort to more clearly examine the depth- or seasonal-related abundance of freshwater diplonemids, we carried out multiple sampling campaigns with different sampling frequencies at this site. The first campaign in Lake Biwa lasted for three months in spring/summer 2016 and samples were collected from three different depths (Table 1, Supplementary Figure S3). The second campaign lasted throughout the year 2017 with a monthly sampling frequency (Table 1, Supplementary Figure S4). A single depth profile was also collected from Lake Ikeda to examine the vertical distribution of diplonemids (Table 1, Supplementary Figure S5). To expand the known distribution of diplonemids outside Japan, we also collected samples from five European lakes (řimov, Medard, Zurich, Constance and Lugano). A complete list of sampling sites and their locations, depths and analyses performed with the samples from each site is given in Table 1.

Amplicon-sequencing was performed for the sampling campaigns from Lake Biwa and Lake Ikeda (Figure 1A, B, C and Supplementary Figure S3, S4, S5). Relative abundance of diplonemid sequences in these samples was always below $1 \%$. A total of 18 sequences were recovered, somewhat more frequently from the hypolimnion. The highest relative abundance was observed in the hypolimnion of Lake Ikeda (100 m), contributing up to $0.96 \%$ of total sequence reads (Figure 1C). Although rare, they were present in nearly all the seasons in Lake Biwa (Figure 1) in both epilimnion (5 m) and metalimnion (10-20 m) but only occasionally in the hypolimnion (50-60 m). The highest amplicon read abundance in Lake Biwa was observed in the hypolimnion of May ( $0.5 \%$ of total sequences, Figure 1A). Diplonemid sequences were more abundant in the epilimnion and 
metalimnion during the early part of the spring and as the stratification developed their numbers increased in the hypolimnion (Figure 1A). However, data from the entire year showed the absence of diplonemid sequences in the hypolimnion during summer and autumn (Figure 1B). This discrepancy could be due to the sample collection in different 118 years (spring sampling in 2016 and monthly sampling in 2017) and depths (50 vs. $60 \mathrm{~m}$ ).

119 However, the low numbers of recovered sequences preclude definitive conclusions 120 regarding seasonal or depth related preferences for diplonemids. Similar results were 121 obtained upon examining the abundance of freshwater diplonemids using an existing 122 shotgun metagenomic timeline from the Řimov reservoir (Figure 1D). Here, diplonemid 123 sequences in the epilimnion were found only during spring or early summer with low 124 abundance (maximum $0.04 \%$ of total eukaryotic 18S rRNA reads) (Figure 1D). In contrast 125 to Lake Biwa, diplonemid sequences were found at all seasons in the hypolimnion of the 126 Řimov reservoir with relatively higher proportions (up to $0.6 \%$ of total metagenomic reads) (Supplementary Table S2) although these samples were pre-filtered with $5 \mu \mathrm{m}$ 128 filters, which may have reduced the number of diplonemids. Moreover, the differences in 129 trophic status and sample collection from different depths (Table 1) might be responsible 130 for the observed variation. It is also relevant to mention that dynamics of diplonemids 131 inferred from raw sequence reads is not fully quantitative, as we observed multiple copies 132 of 18S rRNA in single cell genomes from marine diplonemids (Supplementary Table S1). To further examine the distribution of diplonemids at other locations, we sampled 134 several European lakes for shotgun metagenomics (Table 1). As the sequences obtained 135 by amplicon-sequencing were short (300 bp), we wondered if it was possible to identify 136 longer assembled 18S rRNA sequences from freshwater diplonemids in assembled 137 metagenomic contigs. Additionally, we also used previously available metagenomic 138 samples from the Řimov reservoir [17] and other published metagenomic datasets from 
139 the deep Lake Baikal $[18,19]$. Multiple long sequences were retrieved from all samples

140 except for Lake Baikal and all of them were closely related to the amplicon-derived

141 sequences (See Figure 2). The longest assembled 18S rRNA sequence was $2029 \mathrm{bp}$

142 suggesting the less examined potential for assembled metagenomic sequence data for

143 recovery of long eukaryotic $18 \mathrm{~S}$ rRNA sequences.

144 Long sequences (>300 bp) of diplonemids from the metagenomic datasets allowed

145 us to construct a robust maximum-likelihood phylogenetic tree including all closely

146 related sequences of diplonemids from public databases (Figure 2). We observed that the

147 sequences recovered from geographically distant freshwater lakes were highly similar and

148 appeared to be a sister clade of several marine isolates. High similarity of diplonemid

149 sequences from freshwater lakes of the world reiterates what has been suggested already

150 [32] that geographic distance does not restrict the distribution of protists in freshwater

151 lakes around the world. The freshwater sequences formed a separate freshwater cluster

152 that was separated from the marine cultured and environmental sequences with high

153 bootstrap values, suggesting that freshwater diplonemids diverged from the marine ones

154 and are phylogenetically different. The highly congruent freshwater clade provides

155 conclusive evidence for an evolutionary radiation of diplonemids in freshwater

156 ecosystems. Intriguingly, a single diplonema isolate (accession MF422200) that was

157 obtained from Tokyo Bay also appeared to be part of this freshwater clade. This might

158 suggest that even though this isolate was obtained in the bay of Tokyo (Supplementary

159 Table S3), it is possible that it is actually derived from the freshwater inflow into the bay.

160 Moreover, the freshwater cluster is closely related to the marine isolates (Figure 2) and

161 majority of those isolates were from bay, estuarine and near-shore regions (Supplementary

162 Table S3) further suggesting a habitat transition of diplonemids from marine to

163 freshwaters. 
165 Occurrence, morphology, and potential feeding mode of diplonemids

166 We conducted CARD-FISH with the diplonemid-specific probe 'Diplo1590R' [31]

167 targeting all freshwater and marine sequences, to enumerate their abundance in freshwater

168 lakes. However, the number of CARD-FISH stained cells was too low to confidently

169 assess their abundance and dynamics in all the studied lakes. Their abundance was low

170 even during spring, when $18 \mathrm{~S}$ rRNA read numbers were relatively high. In total, we

171 detected 22 CARD-FISH stained cells from all lakes, again pointing at their rarity in

172 freshwater habitats. However, images of these cells provide some insights about cell size,

173 morphology and potential trophic strategies. All detected diplonemids were ovoid cells in

174 the range of 5-10 $\mu \mathrm{m}$ in length (Figure 3, Supplementary Figure S6). Thus, the freshwater

175 diplonemids observed in the present study are smaller when compared to the cultured

176 marine diplonemids (which are around $20 \mu \mathrm{m}$ in size), and also the ones observed from

177 marine waters by single cell sorting, which are much diverse in size (7-20 $\mu \mathrm{m})$ and shape

$178[20]$.

179 There is little information on the feeding behaviour of diplonemids apart from the

180 consensus that they are heterotrophic. Some studies have also reported diplonemids as

181 mainly benthic dwellers feeding by phagotrophy on bacteria, osmotrophy or by detrivory

$182[33,34]$. Protists of size ranges observed here are also known to be efficient grazers of

183 bacteria in aquatic ecosystems [35-39]. All CARD-FISH positive cells observed here also

184 appeared to contain several bacteria (Figure 3). However, it is impossible to conclude

185 from these images whether or not these microbes are inside the cells (suggesting

186 phagotrophic behavior or symbiosis) or outside (epibionts, commensals, etc.) (Figure 3).

187 Although there is no direct evidence of their feeding behavior from environmental

188 samples, diplonemid sequences were detected from the larger planktonic fractions (180- 
$2000 \mu \mathrm{m})$ in TARA Ocean data and suggested to possess a parasitic or symbiotic lifestyle [40]. Moreover, a recent study reported the presence of endosymbiotic bacteria inside the cells of some cultured diplonemids [41], which might mimic bacterivory. Direct evidence using FLB (fluorescently labelled bacteria) uptake experiments [42,43] are necessary to confirm their phagotrophy on bacteria.

\section{Copy number of 18S rRNA genes in diplonemids}

Diplonemids have divergent rRNA genes and due to the large number of mismatches, they are generally not targeted in diversity studies using universal eukaryotic primers (especially V4 primers) [7,8]). This explains why they remained undetected in a majority of eukaryotic diversity studies in the world oceans until the TARA expedition. TARA strategically used primers targeting the V9 region [3], which is a short region ( 150 bp) considered best to capture a large diversity [10]. Although sequence abundance of diplonemids was high in the global oceanic waters, direct quantitative evidence of their actual abundances is scarce. Only a single study from the Atlantic Ocean quantified the abundance of diplonemids from various depths using CARD-FISH and found their abundance to be $<1 \%$ of total planktonic eukaryotes [31], similar to our observations from freshwaters. In the microscopic analysis we could barely observe CARD-FISH positive cells even in those samples, which had relatively higher sequence numbers assigned to diplonemids. These observations suggest that diplonemids (especially marine ones) possess high copy numbers of divergent $18 \mathrm{~S}$ rRNA genes, that could contribute to their amplified sequence abundance [44]. In order to test this, we analyzed ten previously available single cell genomes from marine diplonemids [20]. These genomes are very incomplete (most complete being 9\%), so the number of actual 18S rRNAs detected in these is likely to be severely underestimated. Even so, we detected multiple $18 \mathrm{~S}$ rRNA 
214 gene sequences in these incomplete genomes (up to 21 sequences $>300 \mathrm{bp}$ in cell_13,

215 Supplementary Table S4). Moreover, the sequences from the same cell did not cluster

216 with each other in a phylogenetic tree in several cases (e.g. cell-13, cell-27 and cell-4sb),

217 suggesting a high intra-genomic diversity of this frequently used gene for assessing protist

218 diversity [44] (Supplementary Figure S2). As the raw sequence data for the single cell

219 genomes are not available, we used the coverage of the contigs to obtain an estimate of

220 18S rRNA copy number (Supplementary Table S4). A conservative estimate, using

221 median coverage of an $18 \mathrm{~S}$ rRNA containing contig vs coverage of the remaining contigs

222 (>3kb) suggests multiple copies of 18S rRNA genes in one single cell (up to 141 copies,

223 Supplementary Table S1 and Supplementary Table S4). Only a single, related isolate

224 genome is available (Diplonema papillatum sp.) with an estimated genome completeness

225 of ca. 30\% (Supplementary Figure S1). We could detect 6 copies of 18 S rRNAs, which

226 appears to be somewhat low [22]. However, we could not estimate the putative number of

227 rRNAs, as coverage information for contigs was not available. Given such wide variations

228 in the number of $18 \mathrm{~S}$ rRNA copies and sequence divergence in the presently available

229 incomplete genomic data, accurate quantifications of protist diversity or abundance by

230 sequencing data alone are expected to remain a pressing issue until improved genomes are

231 available.

232

\section{Conclusions}

234 We describe a clade of freshwater diplonemids from multiple lakes around the world.

235 Freshwater diplonemids are related to cultured marine diplonemids and distinct from the

236 as yet uncultured marine diplonemids. Direct observations using CARD-FISH also

237 suggest that freshwater diplonemids are consistently smaller in size in comparison to those

238 from the marine habitat. Although diplonemid 18S rRNA gene sequences were found to 
239 be highly abundant in marine waters [3], a prior quantification of marine diplonemids

240 using CARD-FISH suggests that they are rare components of the marine habitat [31]. It

241 has also been recently suggested that estimates from amplicon sequencing are far from

242 quantitative $[44,45]$. Taken together with the highly divergent and multiple $18 \mathrm{~S}$ sequences

243 derived from single diplonemid cells, it appears the actual abundances of marine

244 diplonemids using sequence data might have been overestimated. Direct counts by

245 CARD-FISH using an identical probe that targets both freshwater and marine clades

246 suggest that diplonemid abundances in both marine and freshwater ecosystems are very

247 low. However, amplicon-sequencing results from both habitats are drastically different,

248 while a large diversity of diplonemid sequences have been obtained from the marine

249 habitat [3], very limited diversity was observed in freshwaters. This suggests that

250 freshwater diplonemids are less diverse than their marine counterparts and their close

251 relationship indicates a recent habitat transition from marine to freshwaters. Nevertheless,

252 it is important to note that this contradictory result of diversity and abundance might not

253 be restricted to diplonemids alone and may also extend to other protistan groups as well

$254[7,43,45]$. Further studies using single-cells, cultures, genome sequencing and

255 experimental approaches will be necessary for an improved understanding of the

256 ecological role and evolutionary history of these poorly understood groups of protists.

\section{Materials and Methods}

259 Sampling: Samples were collected from seven freshwater lakes, in Japan (Biwa- $35^{\circ} 12^{\prime}$

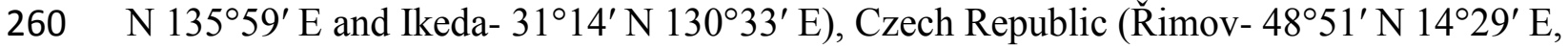
261 and Medard- 50 $10^{\prime} \mathrm{N} 12^{\circ} 35^{\prime} \mathrm{E}$ ), and Switzerland (Zurich- $47^{\circ} 18^{\prime} \mathrm{N} 8^{\circ} 34^{\prime} \mathrm{E}$, Lugano-

$26245^{\circ} 59^{\prime} \mathrm{N} 8^{\circ} 58^{\prime} \mathrm{E}$, and Constance- $47^{\circ} 32^{\prime} \mathrm{N} 9^{\circ} 31^{\prime} \mathrm{E}$ ) (Table 1). All these lakes are $>100 \mathrm{~m}$

263 deep with the exception of the Řimov reservoir and Medard, which are 43 and 50m deep, 
respectively. Samples from Lake Biwa, Japan were collected from three depths representing epilimnion, metalimnion and hypolimnion from station Ie-1, a long-term limnological survey station of Kyoto University, Japan. These samples were collected monthly for one year in 2017 (from depths 5, 20 and $60 \mathrm{~m}$ ) and also from a high frequency weekly sampling, which was conducted for three months during the spring of 2016 (from depths 5, 10 and 50 m) (Table 1). Samples from the Řimov Reservoir, Czech Republic were collected seasonally for two years (2016 and 2017) from two depths (0.5 and $30 \mathrm{~m}$ ), representing epilimnion and hypolimnion (Table 1) from a station located at the dam (deepest part of the reservoir). For other lakes, samples were collected once or twice during the thermal stratification period from depths representing the epilimnion and hypolimnion from stations located at the deepest part of the lakes. Samples were collected with a 5-liter Niskin sampler (General Oceanics, Miami, USA) or with a Freidinger sampler. Temperature, concentration of chlorophyll $a$ and dissolved oxygen was determined with a multiparameter probe (911 plus, Sea Bird Electronics, Inc., USA; or YSI 6600 multiparameter sonde V2, Yellow Springs Instruments, USA) (Figure 1).

DNA extraction, amplicon sequencing and data processing: Amplicon sequencing was conducted only from samples collected from Biwa and Ikeda lakes. Water from the different sampling depths was pre-filtered just after collection using a $20-\mu \mathrm{m}$ mesh plankton net to exclude larger organisms. One to two liters were filtered onto $0.8 \mu \mathrm{m}$ polycarbonate filters (47 $\mathrm{mm}$ diameter, Costar) at low vacuum $(7.5 \mathrm{~cm} \mathrm{Hg})$ and immediately frozen at $-30^{\circ} \mathrm{C}$ until analysis. DNA was extracted with the Power Soil DNA isolation and purification kit (MoBio laboratories, Carlsbad, CA, USA) and quantified using a Nanodrop ND-1000 spectrophotometer (NanoDrop Technologies, Inc., Wilmington, DE, USA). Polymerase chain reactions (PCR) were conducted using 
universal eukaryotic primers Euk1391f and EukBr to amplify the V9 region of $18 \mathrm{~S}$ rRNA genes of all eukaryotes $[9,10]$. PCRs were performed in $25 \mu 1$ of reaction volume according to the 18S Illumina amplicon protocol of the Earth Microbiome Project (http://www.earthmicrobiome.org/protocols-and-standards/18s/). Amplicons were examined using agarose gel electrophoresis and DNA was purified using magnetic beads.

294 Samples were quantified using Qubit. The samples were pooled to have uniform DNA concentration in each and were sequenced using the Illumina MiSeq platform. The searches against the PR2 database [12]. Amplicons with quality score more than Q30 were retained and amplicons were trimmed to have $300 \mathrm{bp}$ using the 'Filter and Trim' function of DADA2. A total of 656,427 reads were obtained after processing. Classification of unique sequences was conducted against the SILVA 132 reference database [13]. The unclassified sequences were additionally examined for their closest relatives with BLAST searches against the NCBI NT database [14].

Filtration and DNA extraction for shotgun metagenomic analysis: Shotgun

$308 \mathrm{~m}$ and $30 \mathrm{~m}$ ), Medard (Czech Republic, depths $5 \mathrm{~m}$ and $20 \mathrm{~m}$ ), Zurich (Switzerland,

309 depths $5 \mathrm{~m}$ and $80 \mathrm{~m}$ ), Constance (Switzerland/Germany, depths $5 \mathrm{~m}$ and $200 \mathrm{~m}$ ) and

310 Lugano (Switzerland/Italy, depths $5 \mathrm{~m}$ and $50 \mathrm{~m}$ ) were progressively filtered through 20

$311 \mu \mathrm{m}, 5 \mu \mathrm{m}$, and $0.22 \mu \mathrm{m}$ polycarbonate or polysulfone membrane filters (Sterlitech, USA).

312 DNA extraction was performed from the $0.22 \mu \mathrm{m}$ filters (containing the $5-0.22 \mu \mathrm{m}$ 
microbial size fraction) using the ZR Soil Microbe DNA MiniPrep kit (Zymo Research,

314 Irvine, CA, USA), following the manufacturer's instructions.

Preprocessing of metagenomic datasets: Shotgun metagenome sequencing was

317 performed with Novaseq $6000(2 \times 151$ bp) (Novogene, HongKong, China). Low quality

318 bases/reads and adaptor sequences were removed from the raw Illumina reads using the

319 bbmap package [15]. Briefly, the reads were quality trimmed by bbduk.sh (using a Phred

320 quality score of 18). Subsequently, bbduk.sh was used for adapter trimming and

321 identification/removal of possible PhiX and p-Fosil2 contamination. Additional checks

322 (i.e., de novo adapter identification with bbmerge.sh) were performed in order to ensure

323 that the datasets meet the quality threshold necessary for assembly. Each metagenomic

324 dataset (i.e. each sample) was assembled independently with MEGAHIT (v1.1.5) [16]

325 using the k-mer sizes: 49, 69, 89, 109, 129, 149, and default settings. Previously available

326 metagenomes and assemblies from Řimov reservoir [17] and Lake Baikal were included

327 in the analysis $[18,19]$.

329 Genomic data processing: Assembled sequence data for single cell derived genomes

330 from 10 published marine diplonemids were downloaded [20]. Genome completeness

331 estimates performed by us (and similar to those reported earlier) for these were found to

332 be very low with the best assembly missing $91 \%$ of conserved single copy orthologs (as

333 reported by BUSCO [21]). The assembled Diplonema papillatum genome [22] was

334 downloaded from NCBI (accession LMZG00000000). Only the assembled genome is

335 available and raw data was not available although it was mentioned to be $21.5 \mathrm{~Gb}$. The

336 genome assembly size is ca. $107 \mathrm{Mb}$ (shortest contig $1000 \mathrm{bp}$, longest contig 100kb). The

337 authors estimated the genome size to be $175 \mathrm{Mb}$, but no details were provided on how this 
338 estimate was obtained [22]. Genome completeness estimates for all available genomes

339 (Diplonema papillatum genome and the 10 marine diplonemid SAGs) were obtained using

340 BUSCO [21] with the euglenozoa lineage (euglenozoa_odb10 version 2019-11-21) (busco

341 -m genome -i genome.fna -o output --lineage_dataset euglenozoa_odb10) (Supplementary

342 Figure S1). Eukaryotic small ribosomal subunit sequences were detected in these genomic

343 assemblies using ssu-align [23]. Only those sequences that were $>300 \mathrm{bp}$ were retained for

344 further analysis. The results are summarized in Supplementary Table S1.

Retrieval of 18S rRNA sequences from assembled shotgun metagenomic datasets: All

347 diplonemid sequences were extracted from the SILVA database version 138 [13]. These

348 sequences along with the freshwater diplonemid sequence (OTU_4) described previously

$349[6]$, were used as queries for BLASTN against the metagenomic datasets. Hits with e-

350 value $<1$ e-5, alignment length $>200$ bp and percentage identity $>90 \%$ to the queries were

351 extracted. These candidate sequences were aligned to the global SILVA alignment for

352 rRNA genes using the SINA web aligner [24] and subsequently inserted into the guide

353 tree of SILVA SSU database 138 RefNR 99 in ARB [25] using maximum parsimony and

354 only those sequences that affiliated to diplonemids and of length $>300 \mathrm{bp}$ were retained.

\section{Quantification of 18S rRNA sequences of freshwater diplonemids in a shotgun}

357 metagenomic time-series from Řimov reservoir: All assembled freshwater diplonemid

358 sequences (from previous section) along with OTU_4 from Lake Biwa [6] were added to

359 the existing SILVA 138 database of 18 S sequences. At least half the reads from each

360 metagenomic dataset (minimum 94 million reads, maximum 277 million reads) were

361 scanned by ssu-align to extract potential eukaryotic $18 \mathrm{~S}$ reads (minimum ca. 65,000 ,

362 maximum 180,000 found) and these were used as queries against the SILVA138 database 
supplemented with freshwater diplonemid sequences using mmseqs2 [26]. Metagenomic query sequences matching the freshwater diplonemid sequences with $>95 \%$ identity, evalue $<1 \mathrm{e}-5$ and alignment length $>50 \mathrm{bp}$ were considered to originate from freshwater diplonemids (Supplementary Table S2).

18S rRNA phylogenetic tree: Assembled 18S rRNA sequences identified to be from freshwater diplonemids were aligned to all known clades of Euglenids using PASTA [27] and a maximum likelihood phylogenetic tree (Figure 2) was made using IQ-TREE 2 using automatic model selection (TIM3e+R10 model), ultrafast bootstraps and SH-aLRT tests (bb 1000 -alrt 1000) [28-30]. Additionally, all $18 \mathrm{~S}$ sequences (>300 bp) from the single cell diplonemid genomes and the Diplonema papillatum genome were aligned to the same set of sequences and a phylogenetic tree (Supplementary Figure S2) was created as described above.

\section{Catalyzed Reporter Deposition-Fluorescent in situ Hybridization (CARD-FISH):}

Samples for CARD-FISH were collected from the same depths as the samples used for DNA extractions (Table 1). Water samples were fixed in a $2 \%$ final concentration of formaldehyde (freshly prepared by filtering through $0.2 \mu \mathrm{m}$ syringe filter) for at least 3-4 hours before filtration. $50 \mathrm{ml}$ of epilimnion/metalimnion and $100 \mathrm{ml}$ of hypolimnion samples were filtered through polycarbonate filters (pore size $0.8 \mu \mathrm{m}$, Advantec), rinsed twice with $1 \mathrm{X}$ PBS and twice with MilliQ water, air dried and frozen at $-20^{\circ} \mathrm{C}$ until further processing. CARD-FISH was performed according to the method described previously [7]. The filters were hybridized at $35^{\circ} \mathrm{C}$ for $12 \mathrm{~h}$ with a $0.5 \mu \mathrm{g} \mathrm{ml} l^{-1}$ probe concentration and a $30 \%$ concentration of formamide. The probe targeting diplonemids 'DiploR1792' [31] was purchased from Biomer, Germany. Counting was performed using an Olympus 
388 BX 53 epifluorescence microscope under $1000 \times$ magnification at blue/UV excitation.

389 Total microbial eukaryotes were counted simultaneously by DAPI staining under UV

390 excitation. Images were taken and processed using a semiautomatic image analysis system

391 (NIS-Elements 3.0, Laboratory Imaging, Prague, Czech Republic).

\section{Data Accessibility}

394 The sequence data of Japanese lakes generated from amplicon sequencing were submitted 395 to European Nucleotide Archive (ENA) and are available under the BioProject:

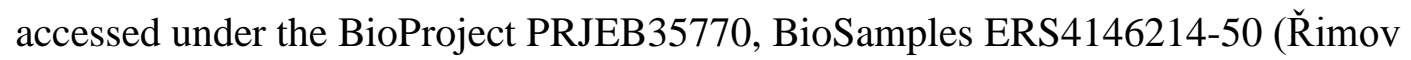
reservoir), BioProject PRJEB35640, BioSamples ERS4065084-85 (Lake Medard),

403 (https://doi.org/10.6084/m9.figshare.12091749.v1). This study did not generate any code.

\section{Author's Contributions}

406 IM and RG conceived the study. IM performed sampling, amplicon analyses and CARD-

410 input of all other authors. 


\section{Competing interests}

414 The authors declare that they have no competing interests.

\section{Funding}

417 This study was supported by the JSPS Bilateral Japanese-Czech Joint Research Project

418 No. JSPS-17-17, funding the collaboration of KS, SN, IM, VG and YH. IM was supported 419 by the research grants CZ.02.1.01/0.0/ 0.0/16_025/0007417 (ERDF/ESF) and 20-12496X

420 (Grant Agency of the Czech Republic). RG was supported by the research grants 17-

421 04828S, 20-12496X (Grant Agency of the Czech Republic) and CZ.02.1.01/0.0/

422 0.0/16_025/0007417 (ERDF/ESF). MMS was supported by the research grants 20-

423 12496X (Grant Agency of the Czech Republic) and 310030_185108 (Swiss National

424 Science Foundation). A-ŞA was supported by the research grants 17-04828S (Grant

425 Agency of the Czech Republic) and MSM200961801 (Academy of Sciences of the Czech

426 Republic). VSK was supported by the research grants 17-04828S, 20-12496X (Grant

427 Agency of the Czech Republic) and 116/2019/P (Grant Agency of the University of South

428 Bohemia in České Budějovice 2019-2021). MH was supported by the research grant

429 310030_185108 (Swiss National Science Foundation). PL was supported by the research

430 grant 19-23469S (Grant Agency of the Czech Republic) and 022/2019/P (Grant Agency of

431 the University of South Bohemia in České Budějovice 2019-2021).

\section{Acknowledgements}

434 We are thankful to the captains of the research vessel 'Hasu', Y. Goda and T. Akatsuka

435 for their help in sample collection in Lake Biwa. We are also thankful to Shohei Fujinaga

436 for his help in sample collection and data analysis. P. Znachor, P. Rychtecky and J.

437 Nedoma are acknowledged for help in sampling of Řimov Reservoir and Lake Medard. T. 
438 Posch, E. Loher and V. Lanta are thanked for help in the sample collection of Lake

439 Zurich. S. Dirren and the crew of the research vessel 'Kormoran' are thanked for help in 440 sampling of Lake Constance, and F. Leporelli and V. Lanta for help in sampling of Lake 441 Lugano.

\section{References}

444 1. Lukeš J, Flegontova O, Horák A. 2015 Diplonemids. Curr. Biol. 25, R702-704.

445 (doi:https://doi.org/10.1016/j.cub.2015.04.052)

2. Lara E, Moreira D, Vereshchaka A, López-García P. 2009 Pan-oceanic distribution of new highly diverse clades of deep-sea diplonemids. Environ. Microbiol. 11, 47-55. (doi:10.1111/j.1462-2920.2008.01737.x)

449 3. de Vargas C, Audic S, Henry N, Decelle J, Mahé F, Logares R, et al. 2015 Eukaryotic 450 plankton diversity in the sunlit ocean. Science 348, 1261605. (doi:

$451 \quad 10.1126 /$ science.1261605)

452 4. Flegontova O, Flegontov P, Malviya S, Audic S, Wincker P, de Vargas C, Bowler C, 453 Lukeš J, Horák A. 2016 Extreme Diversity of Diplonemid Eukaryotes in the Ocean. Curr. 454 Biol. 26, 3060-3065. (doi:10.1016/j.cub.2016.09.031)

455 5. Tashyreva D, Prokopchuk G, Votýpka J, Yabuki A, Horák A, Lukeš J. 2018 Life cycle, 456 ultrastructure, and phylogeny of new diplonemids and their endosymbiotic bacteria. MBio 9, 1-20. (doi:10.1128/mBio.02447-17)

458 6. Mukherjee I, Hodoki Y, Okazaki Y, Fujinaga S, Ohbayashi K, Nakano SI. 2019

459 Widespread Dominance of Kinetoplastids and Unexpected Presence of Diplonemids in 460 Deep Freshwater Lakes. Front. Microbiol. 10, 1-13. (doi:10.3389/fmicb.2019.02375) 
461 7. Mukherjee I, Hodoki Y, Nakano S. 2015 Kinetoplastid flagellates overlooked by

462 universal primers dominate in the oxygenated hypolimnion of Lake Biwa, Japan. FEMS

463 Microbiol. Ecol. 91, 1-11. (doi:10.1093/femsec/fiv083)

464 8. Bochdansky AB, Clouse MA, Herndl GJ. 2017 Eukaryotic microbes, principally fungi 465 and labyrinthulomycetes, dominate biomass on bathypelagic marine snow. ISME J. 11, 466 362-373. (doi:10.1038/ismej.2016.113)

467 9. Amaral-Zettler LA, McCliment EA, Ducklow HW, Huse SM. 2009 A method for 468 studying protistan diversity using massively parallel sequencing of V9 hypervariable 469 regions of small-subunit ribosomal RNA Genes. PLoS One 4, 1-9.

470 (doi:10.1371/journal.pone.0006372)

471 10. Stoeck T, Bass D, Nebel M, Christen R, Jones MDM, Breiner HW, Richards TA. 2010

472 Multiple marker parallel tag environmental DNA sequencing reveals a highly complex

473 eukaryotic community in marine anoxic water. Mol. Ecol. 19, 21-31. (doi:10.1111/j.1365-

$474 \quad 294 X .2009 .04480 . x)$

475 11. Callahan BJ, McMurdie PJ, Rosen MJ, Han AW, Johnson AJA, Holmes SP. 2016

476 DADA2: High-resolution sample inference from Illumina amplicon data. Nat. Methods

477 13, 581-583. (doi:10.1038/nmeth.3869)

478 12. Guillou L, Bachar D, Audic S, Bass D, Berney C, Bittner L, et al. 2013 The Protist

479 Ribosomal Reference database (PR2): A catalog of unicellular eukaryote Small Sub-Unit 480 rRNA sequences with curated taxonomy. Nucleic Acids Res. 41, 597-604.

481 (doi:10.1093/nar/gks1160)

482 13. Quast C, Pruesse E, Yilmaz P, Gerken J, Schweer T, Yarza P, Peplies J, Glöckner FO.

4832012 The SILVA ribosomal RNA gene database project: improved data processing and

484 web-based tools. Nucleic Acids Res. 41, D590-D596. (doi:10.1093/nar/gks1219) 
14. Altschul SF, Gish W, Miller W, Myers EW, Lipman DJ. 1990 Basic local alignment search tool. J. Mol. Biol. 215, 403-410. (doi:10.1016/S0022-2836(05)80360-2)

15. Bushnell B. 2016 BBMap Short-read aligner, and other bioinformatics tools.

Bioinformatics. (doi:https://sourceforge.net/projects/bbmap/)

16. Li D, Luo R, Liu CM, Leung CM, Ting HF, Sadakane K, Yamashita H, Lam TW. 2016 MEGAHIT v1.0: A fast and scalable metagenome assembler driven by advanced methodologies and community practices. Methods 102, 3-11.

(doi:10.1016/j.ymeth.2016.02.020)

17. Kavagutti VS, Andrei AŞ, Mehrshad M, Salcher MM, Ghai R. 2019 Phage-centric ecological interactions in aquatic ecosystems revealed through ultra-deep metagenomics.

Microbiome 7, 0-15. (doi:10.1186/s40168-019-0752-0)

18. Cabello-Yeves PJ, Zemskaya TI, Rosselli R, Coutinho FH, Zakharenko AS, Blinov V V, Rodriguez-Valera F, Drake HL. 2018 Genomes of Novel Microbial Lineages

Assembled from the Sub-Ice Waters of Lake Baikal. Appl. Environ. Microbiol. 84, e02132-17. (doi: 10.1128/AEM.02132-17)

19. Cabello- Yeves PJ, Zemskaya TI, Zakharenko AS, Sakirko M V., Ivanov VG, Ghai R, Rodriguez- Valera F. 2019 Microbiome of the deep Lake Baikal, a unique oxic bathypelagic habitat. Limnol. Oceanogr., lno.11401. (doi:10.1002/lno.11401)

20. Gawryluk RMR, del Campo J, Okamoto N, Strassert JFH, Lukeš J, Richards TA, Worden AZ, Santoro AE, Keeling PJ. 2016 Morphological Identification and Single-Cell Genomics of Marine Diplonemids. Curr. Biol. 26, 3053-3059.

(doi:10.1016/j.cub.2016.09.013)

21. Seppey M, Manni M, Zdobnov EM. 2019 BUSCO: Assessing genome assembly and annotation completeness. In Methods in Molecular Biology, pp. 227-245. Humana Press Inc. (doi:10.1007/978-1-4939-9173-0_14) 
22. Morales J, Hashimoto M, Williams TA, Hirawake-Mogi H, Makiuchi T, Tsubouchi A, et al. 2016 Differential remodelling of peroxisome function underpins the environmental and metabolic adaptability of diplonemids and kinetoplastids. Proc. R. Soc. B Biol. Sci. 283, 20160520. (doi:10.1098/rspb.2016.0520)

23. Nawrocki EP. 2009 Structural alignment and RNA homology search and alignment using covariance models (Ph. D. thesis). Washington University in Saint Louis, School of Medicine. (doi:https://openscholarship.wustl.edu/etd/256/)

24. Pruesse E, Peplies J, Glöckner FO. 2012 SINA: Accurate high-throughput multiple sequence alignment of ribosomal RNA genes. Bioinformatics 28, 1823-1829.

(doi:10.1093/bioinformatics/bts252)

25. Ludwig W, Strunk O, Westram R, Richter L, Meier H, Buchner A, et al. 2004 ARB: a software environment for sequence data. Nucleic Acids Res. 32, 1363-1371.

(doi:10.1093/nar/gkh293)

26. Steinegger M, Söding J. 2017 MMseqs2 enables sensitive protein sequence searching for the analysis of massive data sets. Nat. Biotechnol. 35, 1026-1028.

(doi:10.1038/nbt.3988)

27. Mirarab S, Nguyen N, Guo S, Wang LS, Kim J, Warnow T. 2015 PASTA: Ultra-large multiple sequence alignment for nucleotide and amino-acid sequences. J. Comput. Biol. 22, 377-386. (doi:10.1089/cmb.2014.0156)

28. Quang B, Schmidt HA, Chernomor O, Schrempf D, Woodhams MD, Von Haeseler A, Lanfear R. 2020 IQ-TREE 2: New Models and Efficient Methods for Phylogenetic Inference in the Genomic Era. Mol. Biol. Evol. 37, 1530-1534.

(doi:10.1093/molbev/msaa015) 
533 29. Kalyaanamoorthy S, Minh BQ, Wong TKF, Von Haeseler A, Jermiin LS. 2017

534 ModelFinder: Fast model selection for accurate phylogenetic estimates. Nat. Methods 14,

535 587-589. (doi:10.1038/nmeth.4285)

536 30. Hoang DT, Chernomor O, von Haeseler A, Minh BQ, Vinh LS. 2018 UFBoot2:

537 Improving the Ultrafast Bootstrap Approximation. Molecular biology and evolution. Mol.

538 Biol. Evol. 35, 518-522. (doi:10.5281/zenodo.854445)

539 31. Morgan-Smith D, Clouse MA, Herndl GJ, Bochdansky AB. 2013 Diversity and

540 distribution of microbial eukaryotes in the deep tropical and subtropical North Atlantic

541 Ocean. Deep. Res. Part I Oceanogr. Res. Pap. 78, 58-69. (doi:10.1016/j.dsr.2013.04.010)

542 32. Boenigk J, Pfandl K, Stadler P, Chatzinotas A. 2005 High diversity of the 'Spumella-

543 like' flagellates: An investigation based on the SSU rRNA gene sequences of isolates

544 from habitats located in six different geographic regions. Environ. Microbiol. 7, 685-697.

545 (doi:10.1111/j.1462-2920.2005.00743.x)

546 33. López-García P, Vereshchaka A, Moreira D. 2007 Eukaryotic diversity associated

547 with carbonates and fluid-seawater interface in Lost City hydrothermal field. Environ.

548 Microbiol. 9, 546-554. (doi:10.1111/j.1462-2920.2006.01158.x)

549 34. Roy J, Faktorová D, Benada O, Lukeš J, Burger G. 2007 Description of Rhynchopus

550 euleeides n. sp. (Diplonemea), a free-living marine euglenozoan. J. Eukaryot. Microbiol.

551 54, 137-145. (doi:10.1111/j.1550-7408.2007.00244.x)

552 35. Massana R, Unrein F, Rodríguez-Martínez R, Forn I, Lefort T, Pinhassi J, Not F. 2009

553 Grazing rates and functional diversity of uncultured heterotrophic flagellates. ISME J. 3,

554 588-595. (doi:10.1038/ismej.2008.130)

555 36. Boenigk J, Arndt H. 2002 Bacterivory by heterotrophic flagellates: community

556 structure and feeding strategies. Antonie Van Leeuwenhoek 81, 465-480. (doi:

557 https://doi.org/10.1023/A:1020509305868) 
558 37. Šimek K, Kasalický V, Jezbera J, Horňák K, Nedoma J, Hahn MW, Bass D, Jost S,

559 Boenigk J. 2013 Differential freshwater flagellate community response to bacterial food

560 quality with a focus on Limnohabitans bacteria. ISME J. 7, 1519-1530.

561 (doi:10.1038/ismej.2013.57)

562 38. SŠimek K, Nedoma J, Znachor P, Kasalický V, Jezbera J, Hornňák K, Sed'a J. 2014 A

563 finely tuned symphony of factors modulates the microbial food web of a freshwater

564 reservoir in spring. Limnol. Oceanogr. 59, 1477-1492. (doi:10.4319/lo.2014.59.5.1477)

565 39. Šimek K, Grujčić V, Hahn MW, Horňák K, Jezberová J, Kasalický V, Nedoma J,

566 Salcher MM, Shabarova T. 2018 Bacterial prey food characteristics modulate community

567 growth response of freshwater bacterivorous flagellates. Limnol. Oceanogr. 63, 484-502.

568 (doi:10.1002/lno.10759)

569 40. Lima-Mendez G, Faust K, Henry N, Decelle J, Colin S, Carcillo F, et al. 2015

570 Determinants of community structure in the global plankton interactome. Science $\mathbf{3 4 8}$,

571 1262073. (doi:10.1126/science.1262073)

572 41. George EE, Husnik F, Tashyreva D, Prokopchuk G, Horák A, Kwong WK, Lukeš J,

573 Keeling PJ. 2020 Highly Reduced Genomes of Protist Endosymbionts Show Evolutionary

574 Convergence. Curr. Biol. 30, 925-933.e3. (doi:10.1016/j.cub.2019.12.070)

575 42. Šimek K, Grujčić V, Nedoma J, Jezberová J, Šorf M, Matoušů A, et al. 2019

576 Microbial food webs in hypertrophic fishponds: Omnivorous ciliate taxa are major

577 protistan bacterivores. Limnol. Oceanogr. 64, 2295-2309. (doi:10.1002/lno.11260)

578 43. Grujcic V, Nuy JK, Salcher MM, Jensen M, Simek K. 2018 Cryptophyta as major

579 bacterivores in freshwater summer plankton. ISME J. , 1668-1681. (doi:10.1038/s41396-

$580 \quad 018-0057-5)$

581 44. Caron DA, Hu SK. 2018 Are We Overestimating Protistan Diversity in Nature? Trend

582 Microbiol. 27, 197-205. (doi:10.1016/j.tim.2018.10.009) 
583 45. Piwosz K, Shabarova T, Pernthaler J, Posch T, Šimek K, Porcal P, Salcher MM. 2020

584 Bacterial and Eukaryotic Small-Subunit Amplicon Data Do Not Provide a Quantitative

585 Picture of Microbial Communities, but They Are Reliable in the Context of Ecological

586 Interpretations. mSphere 5. (doi:10.1128/msphere.00052-20)

587

588

589

590

591

592

593

594

595

596

597

598

599

600

601

602

603

604

605

606

607 
Table 1. Details of sampling sites

\begin{tabular}{|c|c|c|c|c|c|c|}
\hline $\begin{array}{l}\text { Lake, } \\
\text { country }\end{array}$ & $\begin{array}{l}\text { Trophic } \\
\text { status }\end{array}$ & $\begin{array}{l}\text { Surface } \\
\text { area }\left(\mathrm{km}^{2}\right)\end{array}$ & $\begin{array}{l}\mathrm{Z} \max \\
(\mathrm{m})\end{array}$ & $\begin{array}{l}\text { Sampling depths } \\
\text { (m) }\end{array}$ & Sampling date & $\begin{array}{l}\text { Analyses } \\
\text { performed }\end{array}$ \\
\hline Biwa, JP & Mesotrophic & 674.0 & 104 & $\begin{array}{l}5,10,50(2016) \\
5,20,60(2017)\end{array}$ & $\begin{array}{l}\text { Mar-May } 2016 \text { (weekly) } \\
2017 \text { (monthly) }\end{array}$ & $\begin{array}{l}\text { AS, CF } \\
\text { AS, CF }\end{array}$ \\
\hline Ikeda, JP & Mesotrophic & 11.0 & 200 & $5,50,100,200$ & 25.11 .2017 & $\mathrm{AS}, \mathrm{CF}$ \\
\hline Řimov, CZ & Eutrophic & 2.1 & 43 & $0.5,30$ & $\begin{array}{l}\text { Apr, Aug, Nov 2016, } \\
2017 \text { (monthly) }\end{array}$ & $\begin{array}{l}\mathrm{MG}, \mathrm{CF} \\
\mathrm{MG}, \mathrm{CF}\end{array}$ \\
\hline Medard, CZ & Oligotrophic & 4.9 & 50 & 5,20 & 09.07.2019 & MG \\
\hline $\begin{array}{l}\text { Constance, } \\
\mathrm{CH} / \mathrm{DE} / \mathrm{AT}\end{array}$ & Mesotrophic & 536 & 252 & 5,200 & 03.07.2018 & $\mathrm{MG}, \mathrm{CF}$ \\
\hline Zurich, $\mathrm{CH}$ & $\begin{array}{l}\text { Oligo- } \\
\text { mesotrophic }\end{array}$ & 88.7 & 136 & 5,80 & $\begin{array}{l}11.07 .2018 \\
13.11 .2019\end{array}$ & $\begin{array}{l}\mathrm{MG}, \mathrm{CF} \\
\mathrm{CF}\end{array}$ \\
\hline $\begin{array}{l}\text { Lugano, } \\
\text { CH/IT }\end{array}$ & Eutrophic & 48.7 & 288 & 5,50 & $\begin{array}{l}02.04 .2019 \\
05.11 .2019\end{array}$ & $\begin{array}{l}\mathrm{MG} \\
\mathrm{CF}\end{array}$ \\
\hline
\end{tabular}

609 Abbreviations: JP, Japan; CZ, Czech Republic; CH, Switzerland; DE, Germany; AT, Austria; IT, 610 Italy; AS, 18S amplicon sequencing, MG, shotgun metagenomics; CF, CARD-FISH 


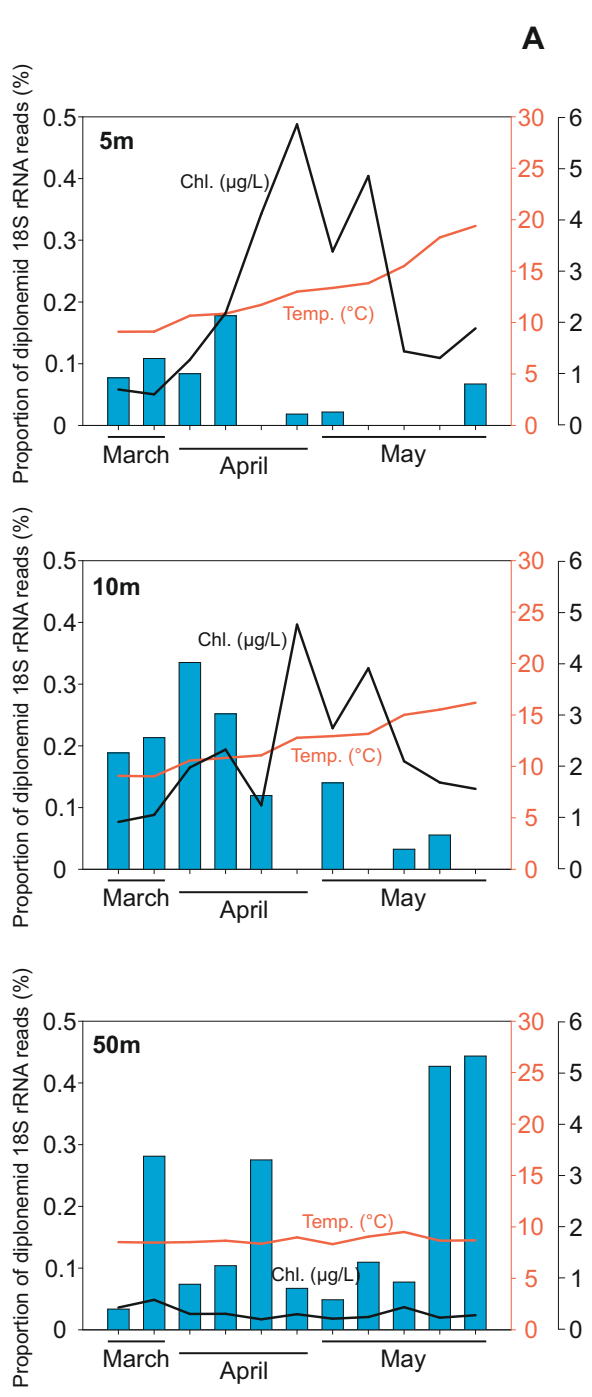

Lake Biwa - Spring 2016
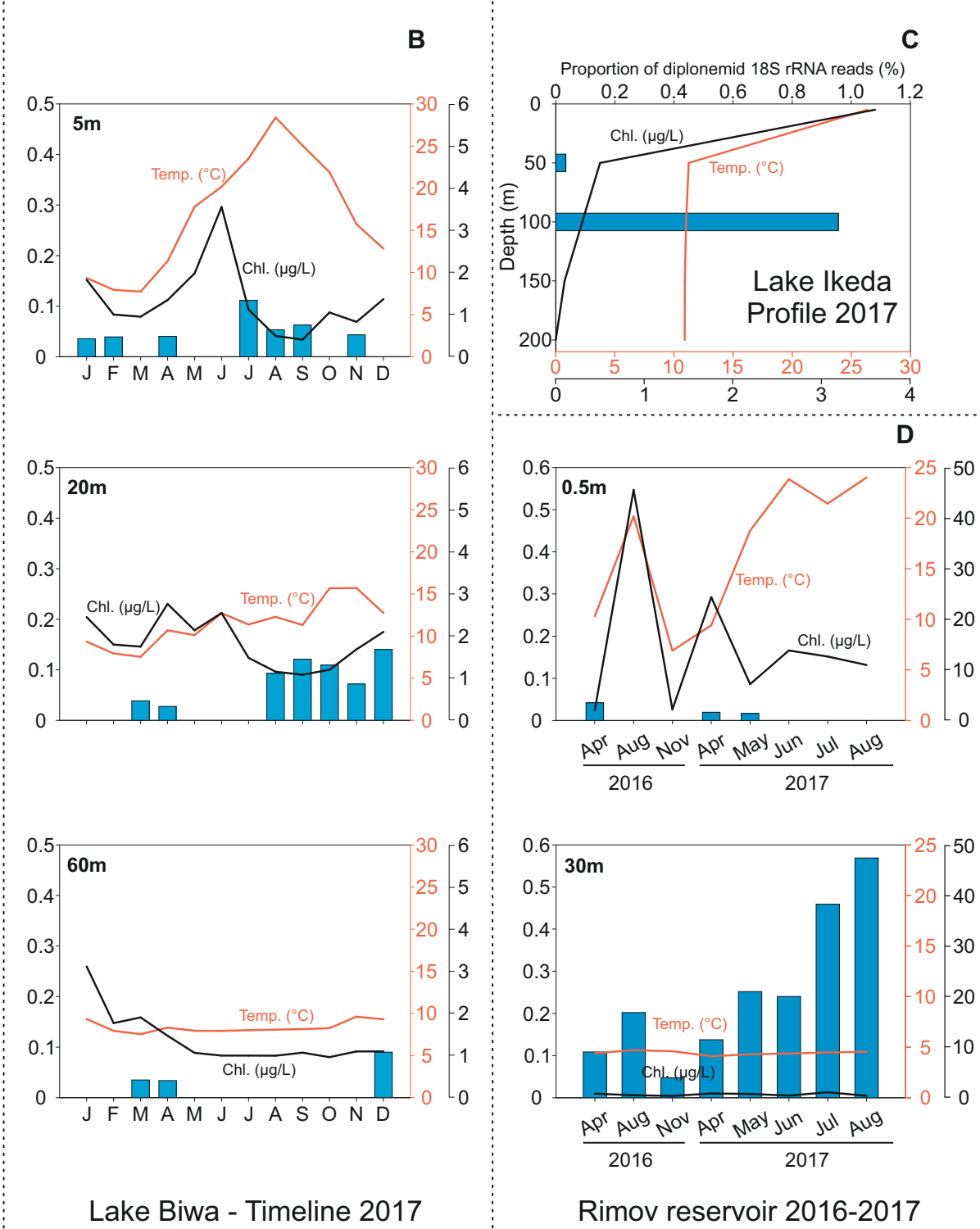

Rimov reservoir 2016-2017

Figure 1. Dynamics of freshwater diplonemids (18S rRNA gene sequence abundance) by A) amplicon sequencing in a weekly spring/summer sampling campaign from Lake Biwa, Japan (depths 5, 10 and 50m), B) amplicon sequencing in a one year sampling campaign from Lake Biwa (depths 5, 20 and 60m) C) shotgun metagenomic time series of the Rimov reservoir, Czech Republic (depths 0.5 and $30 \mathrm{~m}$ ) and D) in a single depth profile from Lake Ikeda (depths 0, 50, 100, 150 and $200 \mathrm{~m})$. 
bioRxiv preprint doi: https://doi.org/10.1101/2020.05.14.095992; this version posted May 15, 2020. The copyright holder for this preprint (which was not certified by peer review) is the author/funder, who has granted bioRxiv a license to display the preprint in perpetuity. It is made available under aCC-BY-NC-ND 4.0 International license.

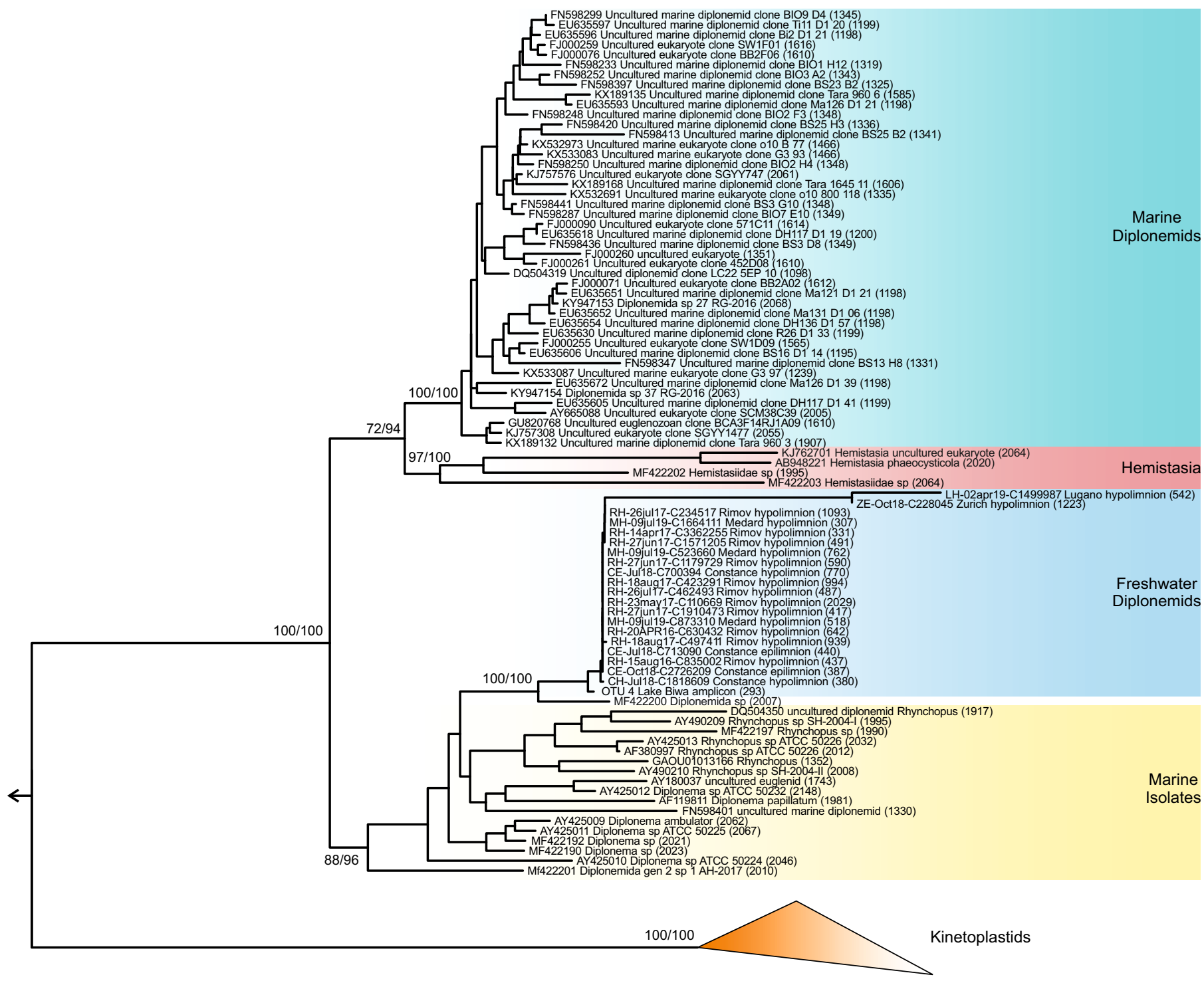

0.4

Figure 2. Maximum-likelihood tree of $18 \mathrm{~S}$ rRNA of diplonemids. Marine diplonemids, Hemistasia, freshwater diplonemids, sequences from isolates and kinteoplastids are shown. Other euglenids (e.g. EUglena, Phacus) were used as outgroup (not shown and indicated by an arrow). Ultra-fast bootstrap values and $\mathrm{SH}$ branch supports are indicated for selected nodes. Scale bar indicates the number of substitutions per site. 
bioRxiv preprint doi: https://doi.org/10.1101/2020.05.14.095992; this version posted May 15, 2020. The copyright holder for this preprint (which was not certified by peer review) is the author/funder, who has granted bioRxiv a license to display the preprint in perpetuity. It is made available under aCC-BY-NC-ND 4.0 International license.

\section{Lake Biwa Řimov Reservoir}

Lake Zurich
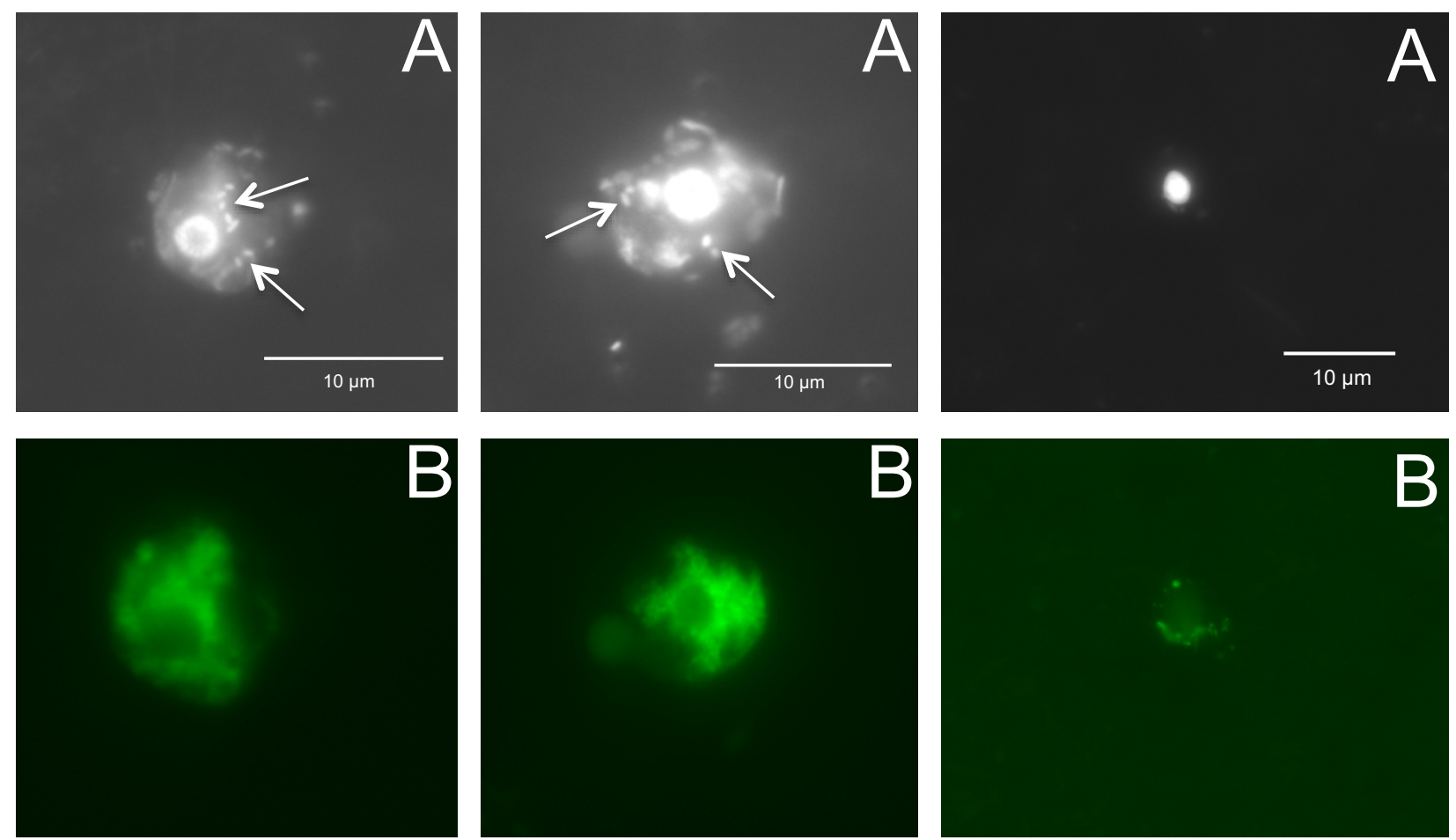

Figure 3. Freshwater diplonemids under fluorescent microscope. A - DAPI, B - FISH, bacteria inside the cells are shown by arrows. 
bioRxiv preprint doi: https://doi.org/10.1101/2020.05.14.095992; this version posted May 15, 2020. The copyright holder for this preprint (which was not certified by peer review) is the author/funder, who has granted bioRxiv a license to display the preprint in perpetuity. It is made available under aCC-BY-NC-ND 4.0 International license.

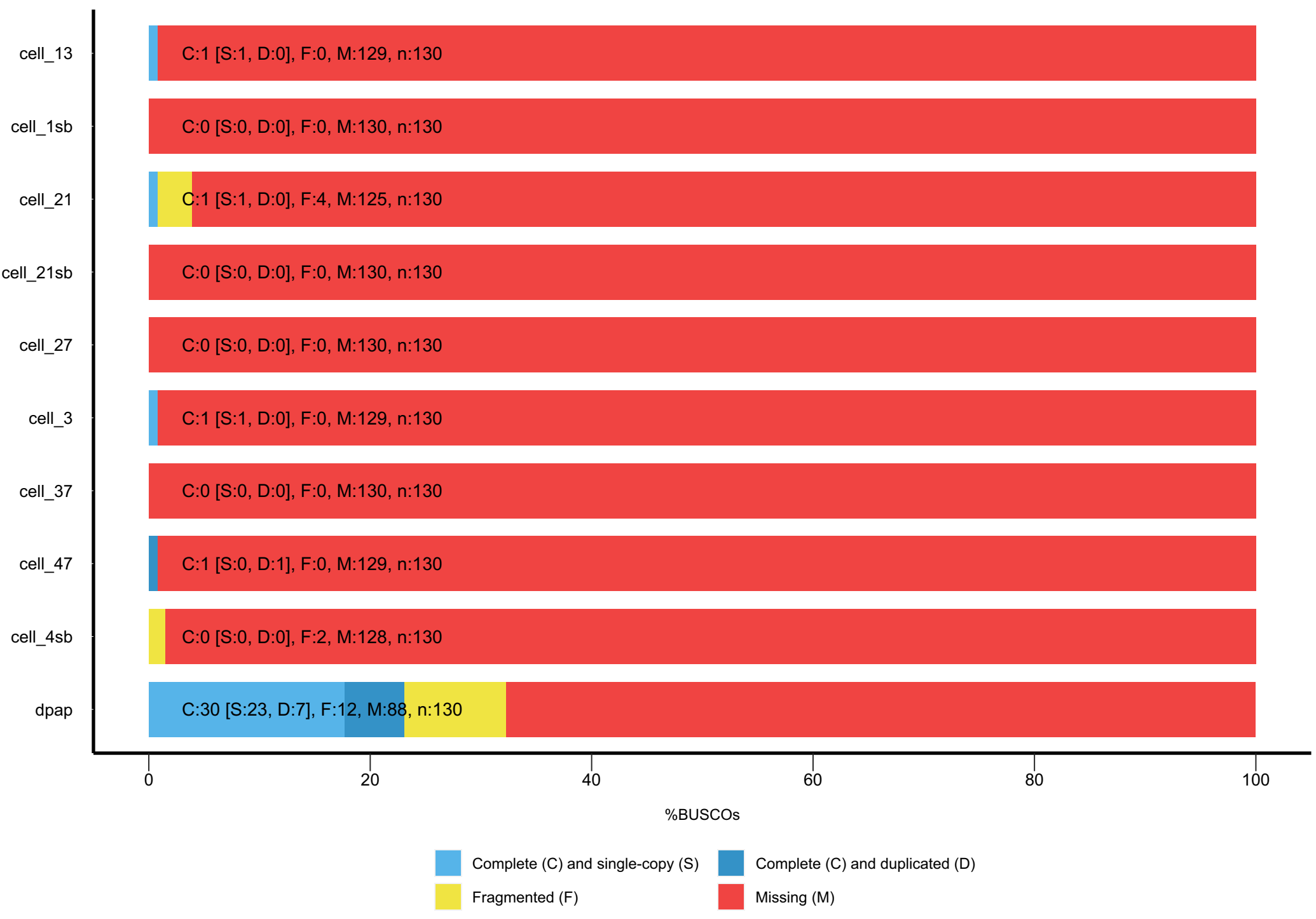

Supplementary Figure S1. Genome completeness estimation for all available diplonemid genomes using BUSCO (Seppey et al. 2019). Single cell genomes are prefixed with "cell", Diplonema papillatum isolate genome: dpap. 


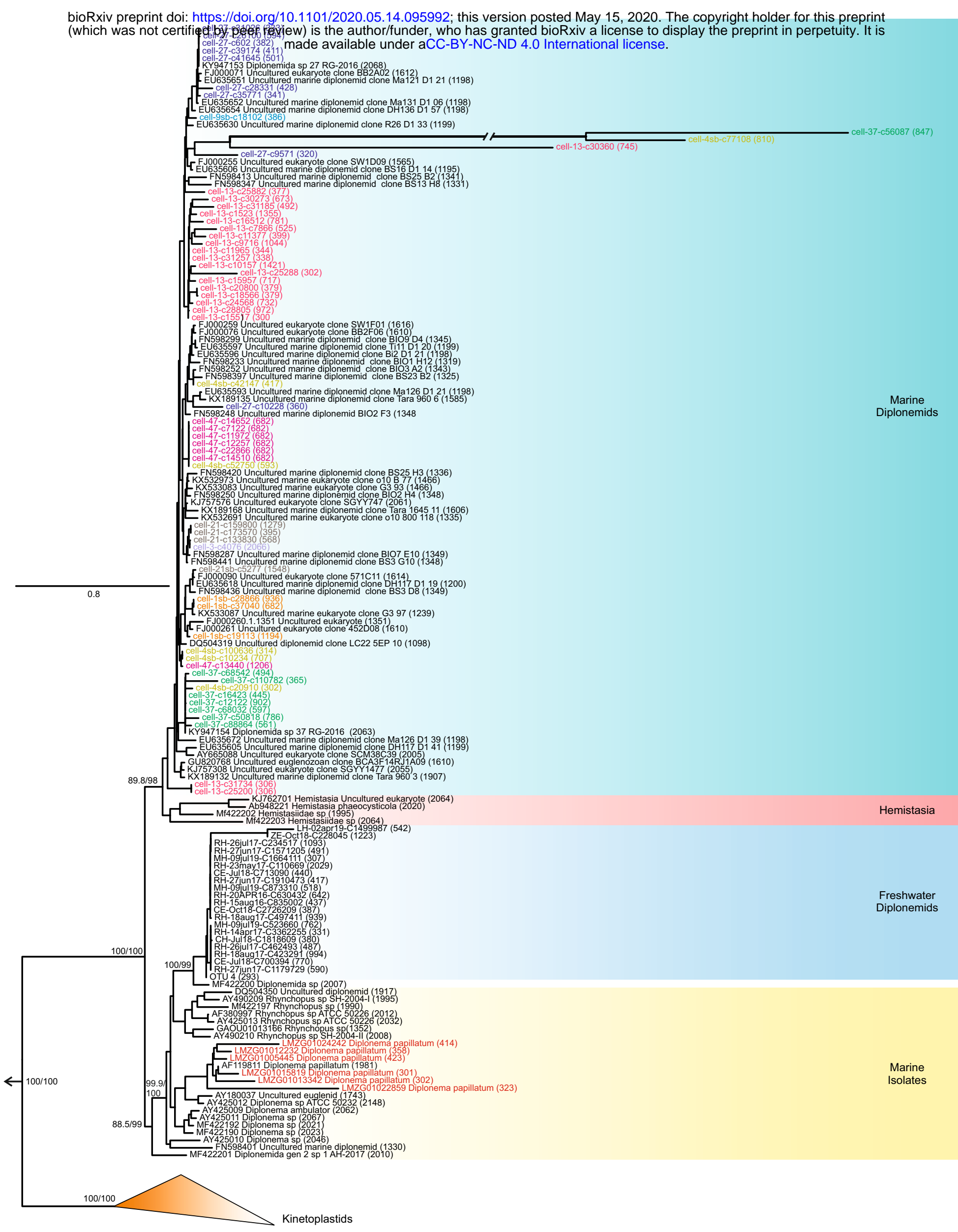

Supplementary Figure S2. Maximum-likelihood tree of 18S rRNA gene sequences of diplonemids highlighting the copy numbers in single cells. 18S rRNA sequences from the genome of single cells were obtained from public databases and are highlighted with same color. D. papillatum group is highlighted in red in marine isolates. Marine diplonemids, Hemistasia, freshwater diplonemids, sequences from isolates and kinteoplastids are also shown. Other euglenids (e.g. Euglena, Phacus) were used as outgroup (not shown and indicated by an arrow). Ultra-fast bootstrap values and $\mathrm{SH}$ branch supports are indicated for selected nodes. The scale bar indicates the number of substitutions per site. 
bioRxiv preprint doi: https://doi.org/10.1101/2020.05.14.095992; this version posted May 15, 2020. The copyright holder for this preprint (which was not certified by peer review) is the author/funder, who has granted bioRxiv a license to display the preprint in perpetuity. It is made available under aCC-BY-NC-ND 4.0 International license.
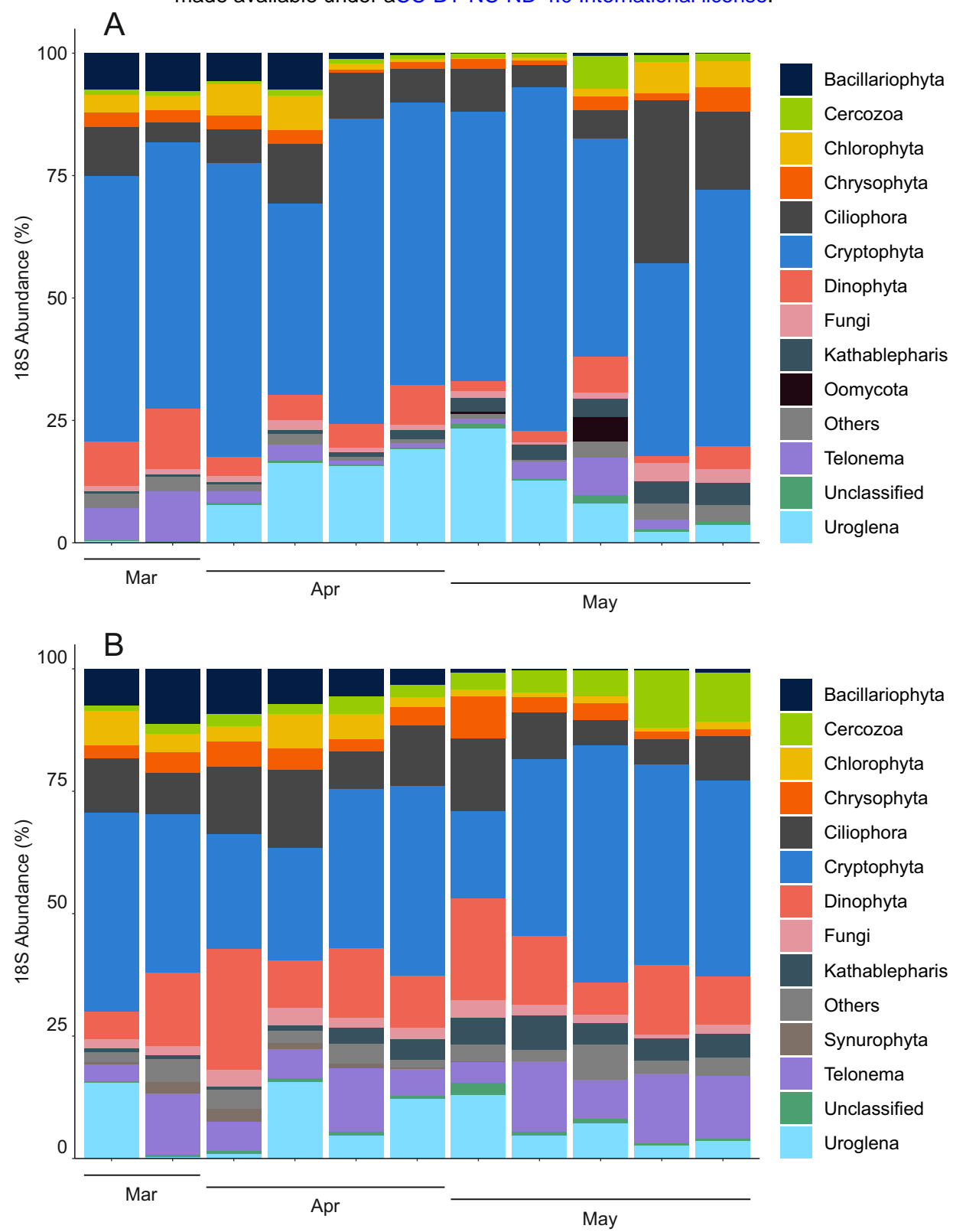

Bacillariophyta

Cercozoa

Chlorophyta

Chrysophyta

Ciliophora

Cryptophyta

Dinophyta

Fungi

Kathablepharis

Others

Synurophyta

Telonema

Unclassified

Uroglena

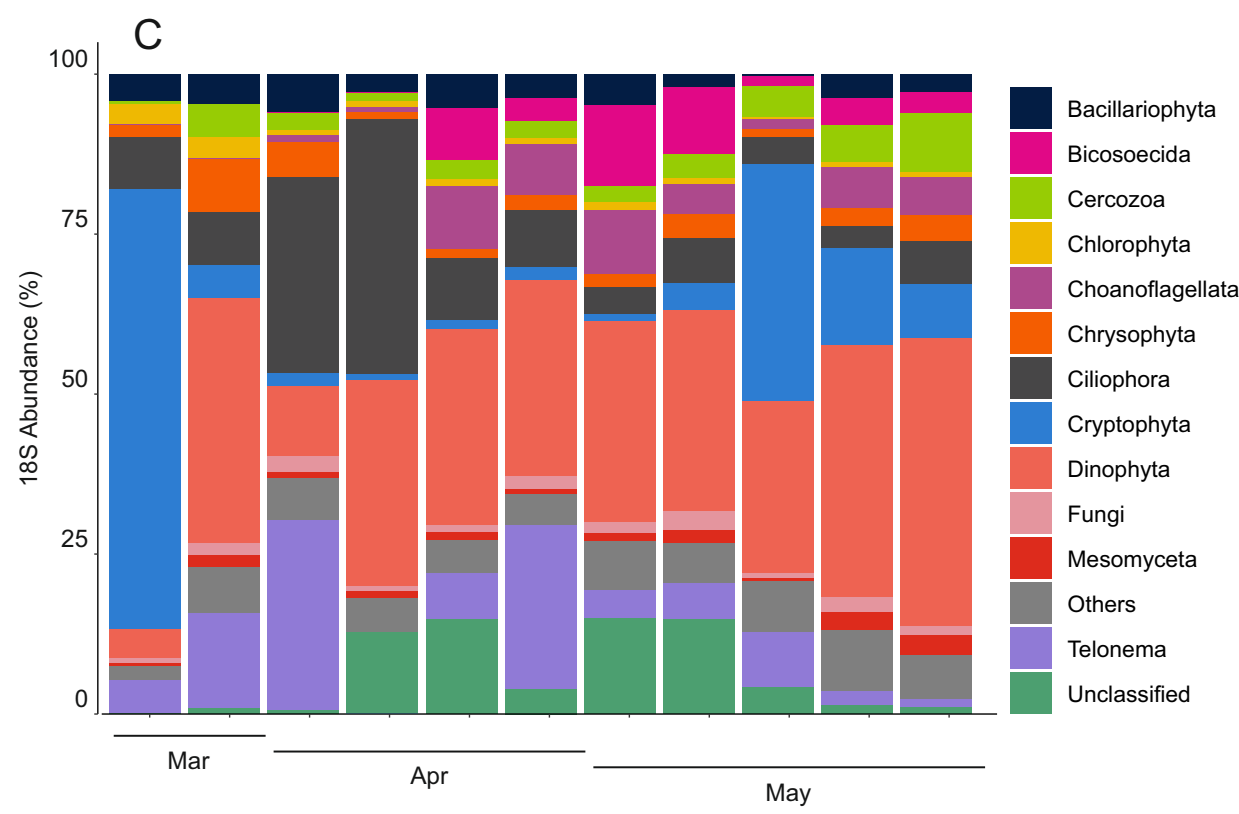

Supplementary Figure S3. Community composition of microbial eukaryotes in Lake Biwa during weekly spring/summer sampling campaign by $18 \mathrm{~S}$ amplicon sequencing from A) Epilimnion (5m), B) Metalimnion (10m) and C) Hypolimnion (50m). 
bioRxiv preprint doi: https://doi.org/10.1101/2020.05.14.095992; this version posted May 15, 2020. The copyright holder for this preprint (which was not certified by peer review) is the author/funder, who has granted bioRxiv a license to display the preprint in perpetuity. It is A made available under aCC-BY-NC-ND 4.0 International license.

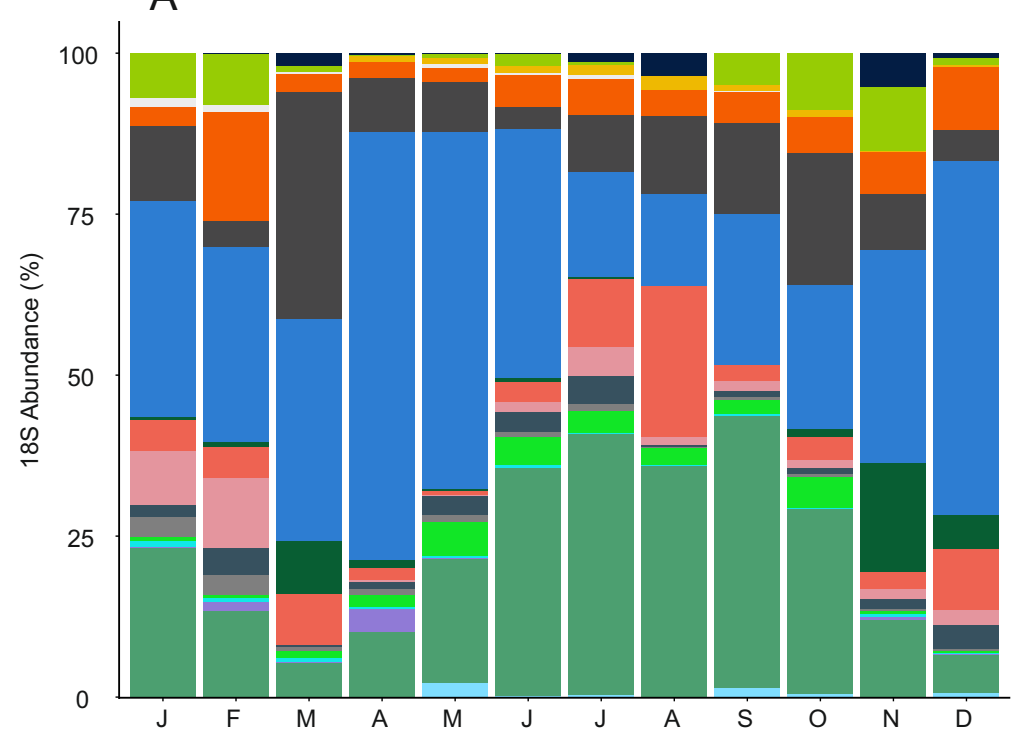

Bacillariophyta

Cercozoa

Chlorophyta

Choanoflagellida

Chrysophyta

Ciliophora

Cryptophyta

Diatom

Dinophyta

Fungi

Kathablepharis

Others

Prymnesiophyta

Stramenopile

Telonema

Unclassified

Uroglena

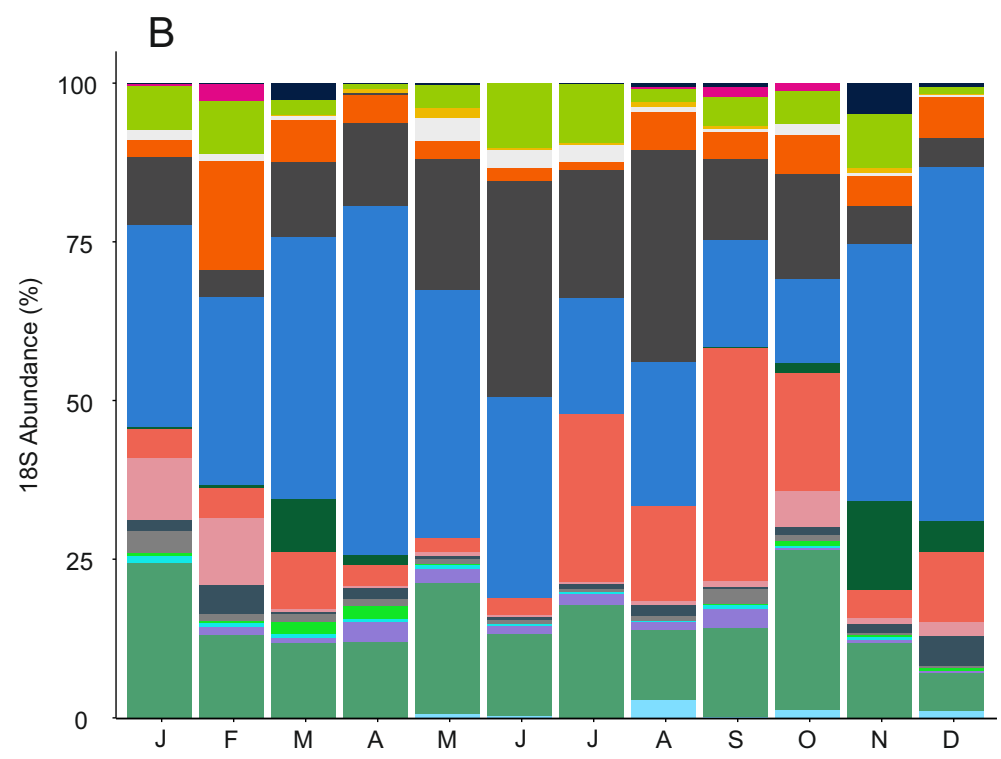

Bacillariophyta

Bicosoecida

Cercozoa

Chlorophyta

Choanoflagellida

Chrysophyta

Ciliophora

Cryptophyta

Diatom

Dinophyta

Fungi

Kathablepharis

Others

Prymnesiophyta

Stramenopile

Telonema

Unclassified

Uroglena

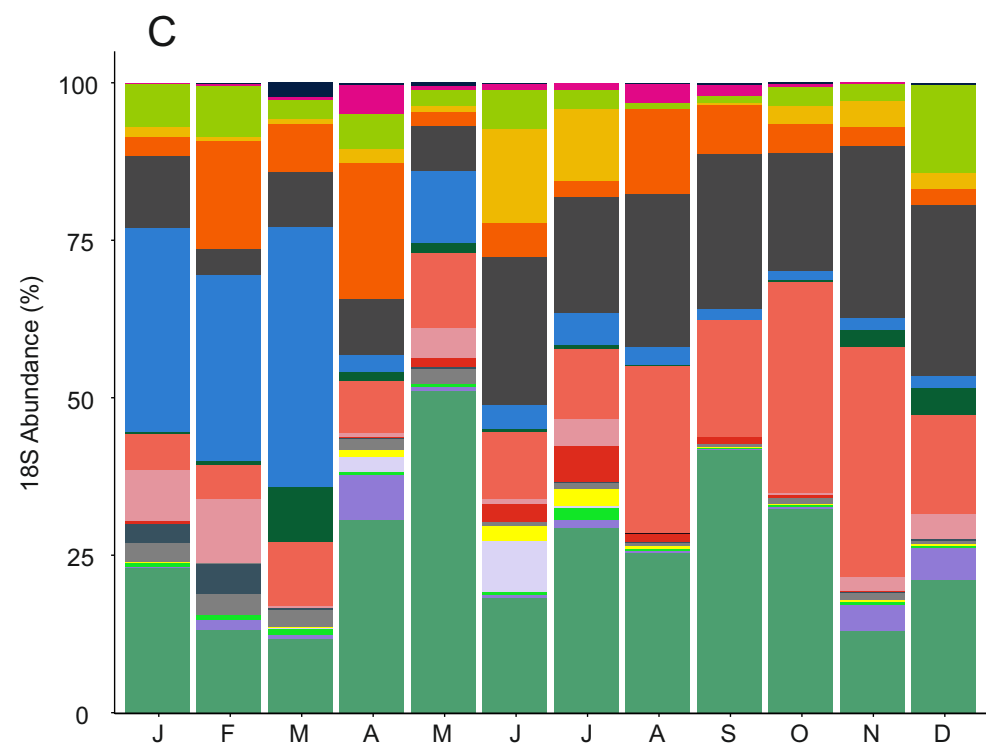

Bacillariophyta
Bicosoecida
Cercozoa
Choanoflagellida
Chrysophyta
Ciliophora
Cryptophyta
Diatom
Dinophyta
Fungi
Heliozoa
Kathablepharis
Others
Pedinella
Perkinsozoa
Stramenopile
Telonema
Unclassified

Supplementary Figure S4. Community composition of microbial eukaryotes in Lake Biwa in 2017 by $18 \mathrm{~S}$ amplicon sequencing from $(A)$ epilimnion $(5 \mathrm{~m}),(B)$ metalimnion $(20 \mathrm{~m})$ and $(\mathrm{C})$ hypolimnion $(60 \mathrm{~m})$ 
bioRxiv preprint doi: https://doi.org/10.1101/2020.05.14.095992; this version posted May 15, 2020. The copyright holder for this preprint (which was not certified by peer review) is the author/funder, who has granted bioRxiv a license to display the preprint in perpetuity. It is made available under aCC-BY-NC-ND 4.0 International license.

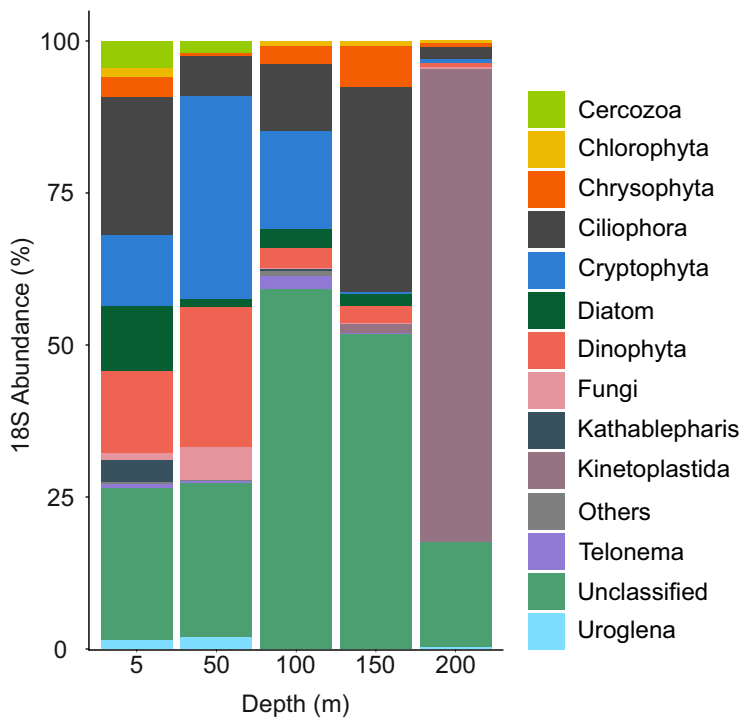

Supplementary Figure S5. Community composition of microbial eukaryotes in various depths of Lake lkeda by $18 S$ amplicon sequencing. 
bioRxiv preprint doi: https://doi.org/10.1101/2020.05.14.095992; this version posted May 15, 2020. The copyright holder for this preprint (which was not certified by peer review) is the author/funder, who has granted bioRxiv a license to display the preprint in perpetuity. It is made available under aCC-BY-NC-ND 4.0 International license.
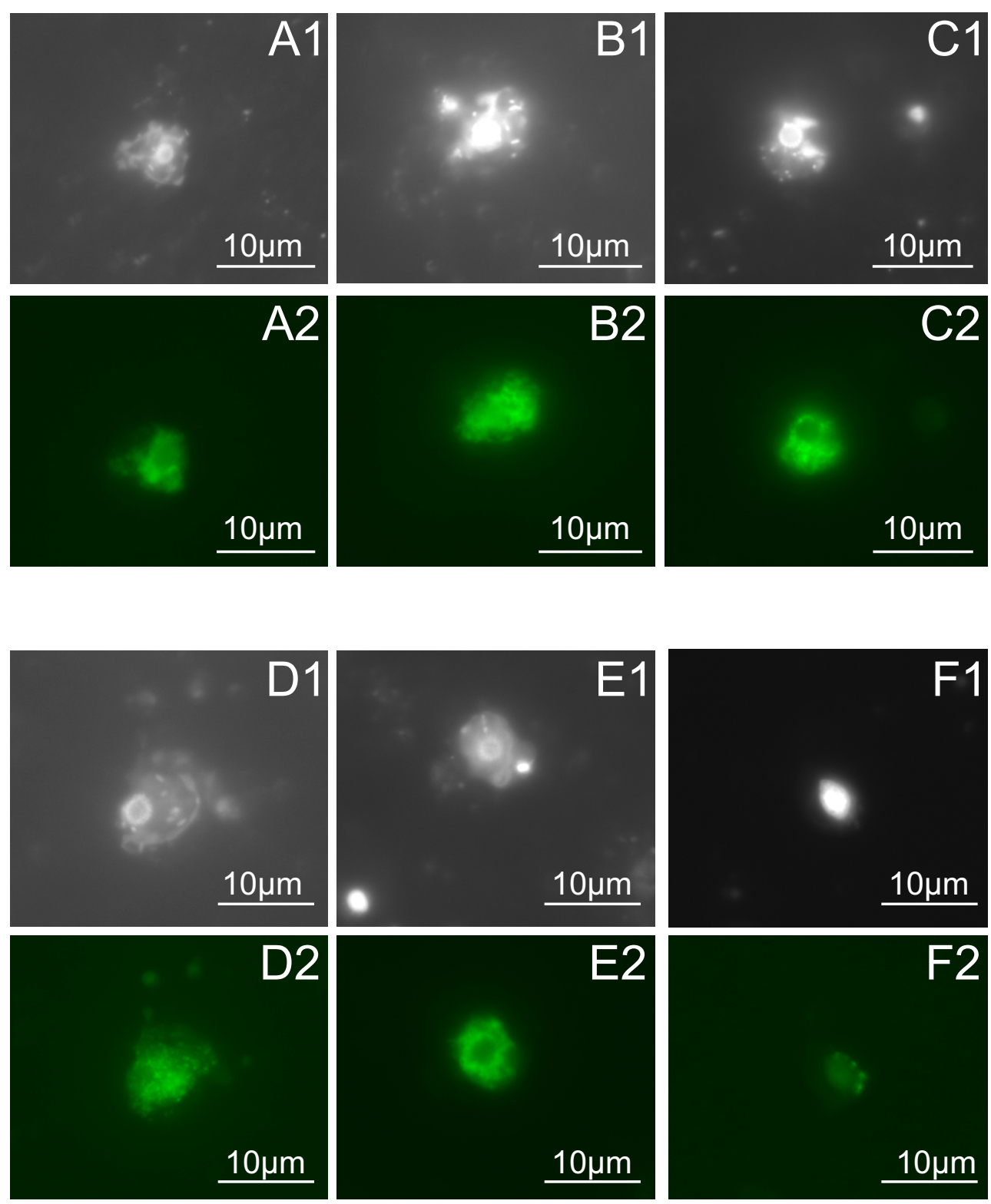

Supplementary Figure S6. Fluorescent microscopic images of freshwater diplonemids from lake Biwa (A-D), Rímov (E) and lake Zurich $(F) .1$ and 2 refers to the same cells visualized by DAPI (under UV excitation) and CARD-FISH (under blue excitation) respectively. 